\title{
The Platelet/Lymphocyte Ratio in Patients with Ischemic Stroke Treated with Intravenous Thrombolysis and Its Relationship with Mortality, Disability, and Prognosis
}

\author{
İntravenöz Tromboliz ile Tedavi Edilen İskemik İnme Hastalarında Platelet/Lenfosit \\ Oranının Mortalite, Disabilite ve Prognoz ile İlișkisi
}

(1) Fettah Eren ${ }^{1}$, (1) Ayșegül Demir¹, (1) Güllü Eren²

1 University of Health Sciences Turkey, Konya Training and Research Hospital, Clinic of Neurology, Konya, Turkey

${ }^{2}$ Necmettin Erbakan University, Meram Faculty of Medicine, Department of Public Health, Konya, Turkey

\begin{abstract}
Introduction: The platelet/lymphocyte ratio (PLR) has been studied frequently to determine the prognosis of cardiovascular diseases, chronic inflammatory diseases, and malignancies. Particularly, the PLR is an indicator of systemic inflammation and atherosclerosis. In this study, we aimed to evaluate the value of the PLR and its relationship with mortality, cerebral hemorrhagic transformation, and short-term prognosis in patients with stroke treated with intravenous thrombolysis.

Methods: Two hundred fifty stroke patients treated with intravenous thrombolysis were included in the study. Initial symptoms, comorbidities, and localization of cerebral ischemia were recorded. Disability was scored on the National Institutes of Health (NIH) stroke scale. At the $24^{\text {th }}$ and $72^{\text {nd }}$ hours after treatment, hemorrhagic transformation was evaluated by brain computed tomography. The in-hospital mortality rate was calculated. Patients were divided into groups according to the difference in the NIH stroke scale (between admission and discharge). Serum platelet and lymphocyte levels and PLR values were determined.
\end{abstract}

Results: There were 128 (51.2\%) female and 122 (48.8\%) male patients included in the study. Their mean age was $71.88 \pm 12.36$ years. The lymphocyte count was low and the PLR was high in patients with a high level of initial disability $(p<0.01)$. The lymphocyte count was higher in patients with clinical improvement $(p=0.023)$. The lymphocyte count was lower and the PLR was higher in patients who died $(p<0.01)$. The platelet level was lower in patients with hemorrhagic transformation $(p=0.024)$. The lymphocyte level and PLR were similar in the hemorrhagic transformation groups $(p=0.156, p=0.675)$.

Conclusion: In this study, it was determined that mortality is related to the PLR, and hemorrhagic transformation is related to platelet levels in patients with ischemic stroke treated with intravenous thrombolysis.

Keywords: Ischemic stroke, intravenous thrombolysis, platelet/ lymphocyte ratio

\section{öZ}

Amaç: Platelet/lenfosit oranı (PLO) kardiyovasküler hastalıkların, kronik enflamatuvar hastalıkların ve malignitelerin prognozunu belirlemek için sıklıkla çalışılmıştır. PLO özellikle sistemik enflamasyonun ve aterosklerozun bir göstergesidir. Bu çalıșmada, intravenöz tromboliz uygulanan inme hastalarında PLO değerinin mortalite, serebral hemorajik transformasyon ve kısa dönem prognoz ile ilişkisini değerlendirmeyi amaçladık.

Yöntemler: Çalıșmaya intravenöz tromboliz ile tedavi edilmiş 250 inme hastası alındı. Bașvuru semptomu, ek hastalıkları ve serebral iskemi lokalizasyonu kaydedildi. Disabilite Ulusal Sağlık Enstitüleri (NIH) inme skalası ile hesaplandı. Tedavi sonrası 24. ve 72. saatlerde beyin bilgisayarlı tomografi ile hemorajik transformasyon değerlendirildi. Hastane içi mortalite oranı hesaplandı. Hastalar başvuru ve taburculuk arası NIH inme skalası sonucu farkına göre gruplara ayrıldı. Serum trombosit, lenfosit seviyesi ve PLO değerleri belirlendi.

Bulgular: Çalıșmada $128(\% 51,2)$ kadın ve $122(\% 48,8)$ erkek

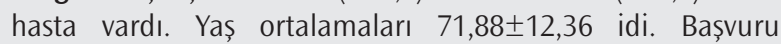
disabilitesi yüksek hastalarda lenfosit sayısı düşük, PLO yüksekti $(p<0,01)$. Klinik düzelme görülen hastalarda lenfosit sayısı yüksekti $(p=0,023)$. Mortal seyredenlerde lenfosit sayısı düşük, PLO yüksekti $(p<0,01)$. Hemorajik transformasyon olan hastalarda platelet seviyesi düşüktü $(p=0,024)$. Lenfosit seviyesi ve PLO hemorajik transformasyon gruplarında benzerdi $(p=0,156, p=0,675)$.

Sonuç: Bu çalıșmada intravenöz tromboliz ile tedavi edilen iskemik inme hastalarında mortalitenin PLO değeri ile hemorajik transformasyonun trombosit düzeyi ile ilişkili olduğu saptanmıştır.

Anahtar Kelimeler: İskemik inme, intravenöz tromboliz, trombosit/lenfosit oranı

Cite this article as/Atıf: Eren F, Demir A, Eren G. The Platelet/Lymphocyte Ratio in Patients with Ischemic Stroke Treated with Intravenous Thrombolysis and Its Relationship with Mortality, Disability, and Prognosis. İstanbul Med J 2021; 22(2): 161-7.

(c) Copyright 2021 by the University of Health Sciences Turkey, Istanbul Training and Research Hospital/istanbul Medical Journal published by Galenos Publishing House.

(C) Telif Hakkı 2021 Sağıı Bilimleri Üniversitesi Istanbul Ĕgitim ve Araştırma Hastanesi/Istanbul Tıp Dergisi, Galenos Yayınevi tarafından basılmıștır. 


\section{Introduction}

Acute ischemic stroke (AIS) is one of the most prevalent causes of mortality and disability; moreover, it imposes a considerable economic and social burden (1). The most common subtype of stroke is ischemic stroke (2). Endovascular treatment (intraarterial thrombolysis, mechanical thrombectomy, etc) and intravenous thrombolytic treatment (IVT) are the most frequently employed treatments for AIS (3). However, some complications occur with recanalization (cerebral hemorrhagic transformations, brain edema and reoclusion, etc). These complications affect mortality and functional status (4).

Platelet activation and aggregation is important in the pathogenesis of AIS. Platelet aggregation induces thrombosis and vascular occlusion. Thus, clinical conditions (such as ischemic stroke and myocardial infarction) occur (5). The immune response is critically important and starts after stroke. Serum leukocytes pass into the cerebral anoxic tissue following disruption of the blood-brain barrier. Neutrophils and lymphocytes are recruited to this area, and the immune response begins with cytokines. Thus, platelets and coagulation factors increase, and the ischemic area expands $(6,7)$.

Blood tests are performed routinely before IVT in patients with AIS (especially hemogram and coagulation tests). The platelet/lymphocyte ratio (PLR) is a more stable test than individual tests for platelets and lymphocytes. It is an easily accessible, inexpensive, and routine test (8). Recent studies have confirmed that the PLR can be used for myocardial infarction, ischemic stroke, pulmonary embolism, and peripheral ischemia (9-11).

In this study, we aimed to determine serum platelet and lymphocyte levels, calculate the PLR value, and evaluate its relationship with inhospital mortality, cerebral hemorrhagic transformation, and short-term prognosis in patients with stroke treated with intravenous thrombolysis.

\section{Methods}

\section{Ethics and Patient Population}

The study was approved by University of Health Sciences Turkey, Konya Training and Research Hospital Ethic Committee (approval number: 3816, date: 08/05/2020). The principles of the Declaration of Helsinki and Guidelines for Good Clinical Practice were adhered to during the study.

The data were collected retrospectively. The study population included AIS patients who were hospitalized and treated with IVT. The purpose and probable complications of IVT were described. Patients or their relatives signed an informed consent form prior to inclusion in the study. Informed consent was obtained from all patients and/or their relatives routinely before IVT. Some diseases (that could affect the study data) were excluded (Table 1). Patients were questioned about their age, gender, and any chronic diseases they might have (hyperlipidemia, hypertension, diabetes mellitus, etc). Initial symptoms were grouped as consciousness, sensory, hemi/mono-paresis, cerebellar, and others (cranial neuropathy, dysarthria/aphasia, dysphagia, convulsion, cortical blindness, delirium).

The data were collected from patients hospitalized in the neurology clinic between January 2013 and March 2020. Three hundred twenty
AIS patients treated with IVT were included in the study. However, 70 patients were excluded from the study due to comorbid diseases and missing data. The data on 250 AIS patients were included.

\section{Definition of the Treatment Period}

The treatment was administered according to AIS early treatment management recommendations of the American Heart Association/ American Stroke Association (3). Before treatment, diagnosis of ischemic stroke and affected vascular areas were confirmed by brain computed tomography (CT) and cerebral CT angiography. Vascular occlusions were divided into two groups, anterior and posterior. If treatment was not contraindicated, alteplase $(0.9 \mathrm{mg} / \mathrm{kg}$, maximum $90 \mathrm{mg}$ ) was started (10\% in 1 minute, the remaining dose in 1 hour, intravenously). If the neurological examination was disrupted after treatment, brain CT was immediately performed. Otherwise, brain CT was routinely performed at the $24^{\text {th }}$ and $72^{\text {nd }}$ hours after treatment. As a result of these neuroimaging studies, intracerebral hemorrhage was evaluated. Patients were divided into two groups (cerebral hemorrhagic transformation positive or negative).

Disability was scored before treatment using the National Institutes of Health (NIH) stroke scale (12). A decrease (between discharge and baseline) of five points or more of the NIH stroke scale score was accepted as clinical improvement. All other patients were scored as "no clinical improvement". Mortality was calculated.

\section{Blood Tests}

Blood samples were obtained before IVT from the antebrachial vein. Hemogram was tested with an Automated Blood Cell Analyzer (Pentra 120 Retic Hematology Analysis Device, ABX, Montpellier, France). Platelet and lymphocyte results were obtained from the hemogram test. After the test, PLR was calculated using the formula "PLR=platelet count/lymphocyte count".

\section{Statistical Analysis}

Data were analyzed with SPSS version 17.0 statistical package software (SPSS Inc., Chicago, IL, United States). Mean \pm standard deviation and median (minimum-maximum) values were used to summarize numerical data. Categorical data were summarized as number (n) and percentage (\%). Categorical data were compared with a chi-square test or Fisher's exact test. The distribution of the data was evaluated with Kolmogorov-Smirnov and Shapiro-Wilk tests. Comparisons of numerical

Table 1. Inclusion and exclusion criteria for the study Inclusion criteria

- Patients with acute ischemic stroke treated with intravenous thrombolysis

Over the age of 18

Exclusion criteria

Chronic liver diseases, rheumatologic, hematological diseases

Malignancies

-Presence of active infection

- History of chronic disease requiring transfusion

Current therapy with steroids or nonsteroidal anti-inflammatory drugs 
data between two groups were performed with a Student's t-test or a Mann-Whitney $U$ test (according to the data distribution). The cutoff point for the PLR was calculated according to receiver operating characteristic (ROC) curve analysis. The cut-off point was determined according to the sensitivity and specificity values. The area under the curve (AUC) was calculated. The $95 \%$ confidence interval $(95 \% \mathrm{Cl})$ was determined. The relationship between numerical data was evaluated with the Spearman correlation test. Correlation coefficients were defined as follows: 0-0.25 weak, 0.25-0.50 weak-medium, 0.50-0.75 strong, and $0.75-1.00$ very strong correlation. Results were considered statistically significant at $p<0.05$.

\section{Results}

\section{General Results}

Two hundred fifty patients [128 (51.2\%) female and 122 (48.8\%) male] treated with IVT were included in the study. The mean age was $72.88 \pm 12.39$. The most common initial symptom was hemi/monoparesis $(n=211,84.4 \%)$. Ischemia was detected especially in the anterior vascular areas $(n=205,82.0 \%)$. Hypertension was the most common chronic disease ( $n=167,66.8 \%)$. Patients demographic characteristics and blood values are summarized in Table 2.

Clinical improvement was higher in patients with a high NIH stroke scale score $(p<0.001)$. Also, mortality and hemorrhagic transformation were higher in these patients $(p<0.001, p=0.009)$. Patients treated with IVT in less than 3 hours had better clinical improvement $(p=0.042)$. There was no difference in hemorrhagic transformation or mortality between treatment time groups ( $p>0.05)$. The mean age of patients with clinical

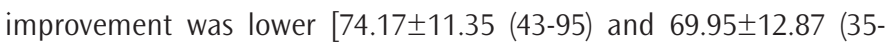
95)]. Blood values of all patients were serum platelet $\left(10^{3} / \mathrm{mm}^{3}\right)$ level $245.49 \pm 80.83$ (107-559), lymphocyte $\left(10^{3} / \mathrm{mm}^{3}\right)$ level $2.10 \pm 0.89(0.56$ 6.87), and PLR value 136.59 \pm 78.38 (24.16-622.35).

\begin{tabular}{|c|c|c|c|}
\hline & & Number (n) & Percentage (\%) \\
\hline \multirow{2}{*}{ Gender } & Female & 128 & 51.2 \\
\hline & Male & 122 & 48.8 \\
\hline \multirow{4}{*}{$\begin{array}{l}\text { Symptom- } \\
\text { treatment time }\end{array}$} & 0-1 hour & 2 & 0.8 \\
\hline & $1-2$ hours & 44 & 17.6 \\
\hline & $2-3$ hours & 92 & 36.8 \\
\hline & $3-4.5$ hours & 112 & 44.8 \\
\hline \multirow{5}{*}{ Initial symptom } & Consciousness & 104 & 41.6 \\
\hline & Hemi/mono-paresis & 211 & 84.4 \\
\hline & Sensory symptoms & 118 & 47.2 \\
\hline & Cerebellar disorder & 16 & 6.4 \\
\hline & Others & 139 & 55.5 \\
\hline \multirow{2}{*}{$\begin{array}{l}\text { Ischemia } \\
\text { Iocalization }\end{array}$} & Anterior & 205 & 82.0 \\
\hline & Posterior & 70 & 28.0 \\
\hline \multirow{4}{*}{ Chronic diseases } & Diabetes mellitus & 73 & 29.2 \\
\hline & Hypertension & 167 & 66.8 \\
\hline & Hyperlipidemia & 34 & 13.6 \\
\hline & Others & 68 & 27.2 \\
\hline
\end{tabular}

\section{The Association of PLR Levels with Initial Disability}

Patients were compared in two groups according to disability score before IVT ( mild disability $=\mathrm{NIH}$ stroke score $<15$, severe disability $=\mathrm{NIH}$ stroke score $\geq 15)$. There was mild disability in 162 (64.8\%) patients and severe disability in 88 (35.2\%) patients. The PLR was higher in patients with severe disability $(p<0.001)$ (Figure 1). The serum lymphocyte level was lower in the group with severe disability $(p<0.001)$. There was no difference in the platelet level between the two groups $(p=0.236)$. The platelet, lymphocyte, and PLR values of the groups are summarized in Table 3A. A negative correlation was detected between the NIH stroke score and the lymphocyte level $(p=0.026, r=-0.48)$. There was a positive correlation with the PLR level $(p=0.001, r=0.59)$.

In ROC analysis, the PLR cut-off value was calculated as 121.72 with $62.5 \%$ sensitivity and $61.0 \%$ specificity ( $p=0.000$, AUC: $0.651,95 \% \mathrm{Cl}$ : $0.58-0.72$ ) (Figure 2). The lymphocyte cutoff value was calculated as 1.86 with $66 \%$ sensitivity and $65 \%$ specificity ( $p=0.000$, AUC: $0.694,95 \% \mathrm{Cl}$ : $0.62-0.76)$.

\section{The Association of PLR Levels with Clinical Improvement}

Patients were divided into two groups according to the difference in the NIH stroke scale, and the groups were compared. There was clinical improvement in 136 (54.4\%) patients and not in 114 (45.6\%). There was no statistically significant difference between the degree of clinical improvement and the PLR ( $p=0.072)$. The serum lymphocyte level was higher in patients in the group with clinical improvement $(p=0.023)$. There was no difference between groups in the serum platelet levels $(p=0.390)$. The platelet, lymphocyte, and PLR values of the groups are summarized in Table 3B.

In ROC analysis, the lymphocyte cut-off value was calculated as 1.95 with $56.6 \%$ sensitivity and $54.4 \%$ specificity $(p=0.023$, AUC: $0.584, \mathrm{Cl}$ : $0.51-0.65)$.

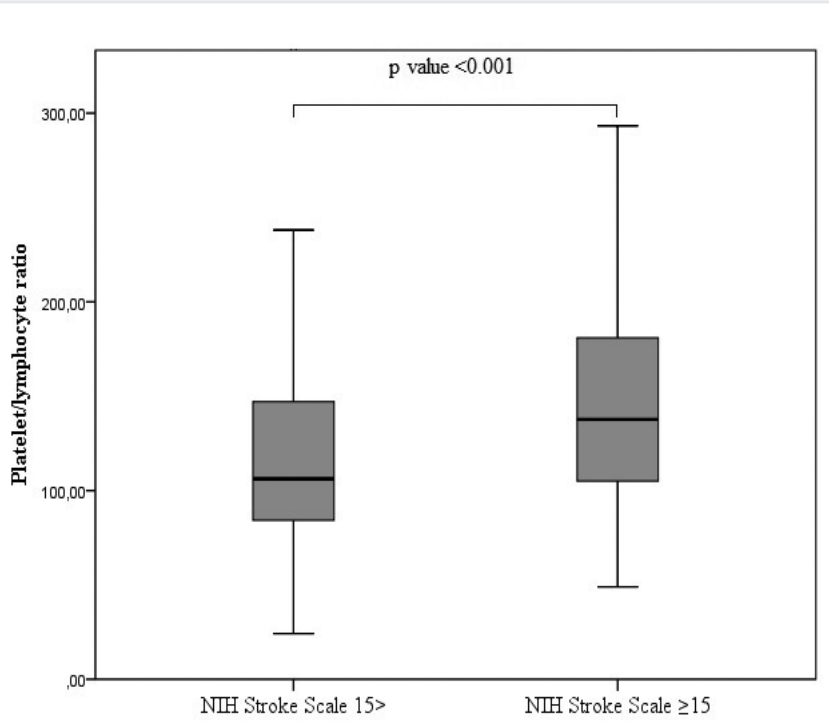

Figure 1. Box plot graph: platelet/lymphocyte ratio according to initial disability in patients treated with intravenous thrombolysis

NIH: National Institutes of Health 
Table 3. Blood parameters according to disability, clinical improvement, mortality, and hemorrhagic transformation. Data are shown as mean \pm standard deviation and min-max

Platelet $\left(10^{3} / \mathrm{mm}^{3}\right)$

Lymphocytes $\left(10^{3} / \mathrm{mm}^{3}\right)$

Platelet/lymphocyte ratio

B

Platelet $\left(10^{3} / \mathrm{mm}^{3}\right)$

Lymphocytes $\left(10^{3} / \mathrm{mm}^{3}\right)$

Platelet/lymphocyte ratio

C

Platelet $\left(10^{3} / \mathrm{mm}^{3}\right)$

Lymphocytes $\left(10^{3} / \mathrm{mm}^{3}\right)$

Platelet/lymphocyte ratio

D

Platelet $\left(10^{3} / \mathrm{mm}^{3}\right)$

Lymphocytes $\left(10^{3} / \mathrm{mm}^{3}\right)$

Platelet/lymphocyte ratio

NIH: National Institutes of Health
NIH stroke scale $<15(n=162)$

$249.50 \pm 79.84$

$2.30 \pm 0.90$

$123.7 \pm 67.3$

$108-559$

0.56-6.87

24.1-579.5

Clinical improvement (-) $(n=114)$

$241.53 \pm 77.95$

107-529

$2.00 \pm 0.97$

$145.61 \pm 86.23$

$0.64-6.87$

24.1-622.3

Mortality (-) $(\mathbf{n}=\mathbf{2 1 9})$

\begin{tabular}{l|l}
$246.21 \pm 77.82$ & $108-559$
\end{tabular}

$2.18 \pm 0.88$

$129.25 \pm 67.70$

0.56-6.87

24.1-579.5

Hemorrhagic transformation $(-)(n=223)$

$249.07 \pm 80.81$

107-559

$2.13 \pm 0.90$

$137.45 \pm 80.20$

0.56-6.87

24.1-622.3
NIH stroke scale $\geq \mathbf{1 5}(\mathrm{n}=\mathbf{8 8})$

$238.11 \pm 82.58$

$1.74 \pm 0.77$

$160.3 \pm 91.1$

Clinical improvement $(+)(n=136)$

$248.80 \pm 83.32$

$2.09 \pm 0.82$

$129.03 \pm 70.58$

$108-559$

0.56-4.70

40.5-579.5

p

Mortality $(+)(n=31)$

$240.41 \pm 99.96$

107-529

$1.55 \pm 0.83$

$188.4 \pm 120.5$

0.64-3.86

48.9-622.3

Hemorrhagic transformation $(+)(n=27)$

$215.92 \pm 76.19$

108-418

$0.66-3.86$

$3.86 \pm 1.90$

48.9-305.8

$129.60 \pm 61.98$
0.292

$<0.001$

0.024

0.236

$<0.001$

$<0.001$

0.390

0.053

0.072

0.001

0.156

0.675

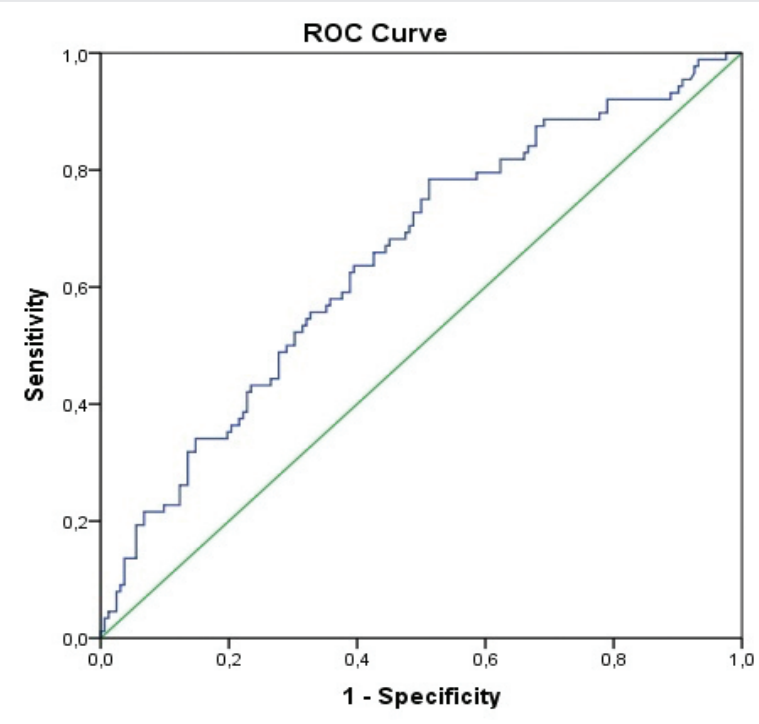

Figure 2. Receiver operating characteristic curve analysis: platelet/ lymphocyte ratio according to initial disability in patients treated with intravenous thrombolysis

ROC: Receiver operating characteristic

\section{The Association of PLR Levels with In-hospital Mortality}

The in-hospital mortality rate was $12.4 \%(n=31)$. The PLR was higher in patients with mortality $(p<0.001)$ (Figure 3$)$. Serum lymphocyte levels were lower in these patients $(p=0.001)$. There was no between-group difference in platelet levels $(p=0.236)$.

In ROC analysis, PLR cutoff value was calculated as 131.43 with $61.3 \%$ sensitivity and $63.0 \%$ specificity ( $p=0.001$, AUC: $0.668, \mathrm{Cl}: 0.58-0.79$ ) (Figure 4). The lymphocyte cut-off value was calculated as 1.66 with $68.8 \%$ sensitivity and $67.7 \%$ specificity $(p=0.000$, AUC: $0.735, \mathrm{Cl}: 0.63-$ $0.83)$.



Figure 3. Box plot graph: platelet/lymphocyte ratio according to in-hospital mortality in patients treated with intravenous thrombolysis

\section{The Association of PLR Levels with Hemorrhagic Transformation}

The hemorrhagic transformation rate was $10.8 \%(n=27)$. The serum platelet level was lower in patients with hemorrhagic transformation $(p=0.024)$ (Figure 5). There was no difference between the lymphocyte level and PLR in these patients $(p=0.156, p=0.675)$. The platelet, lymphocyte, and PLR values of the groups were summarized in Table 3D.

In ROC analysis, the platelet cut-off value was calculated as 211.0 with $67.7 \%$ sensitivity and $63.0 \%$ specificity ( $p=0.024$, AUC: $0.633, \mathrm{Cl}: 0.51-$ 0.75) (Figure 6). 


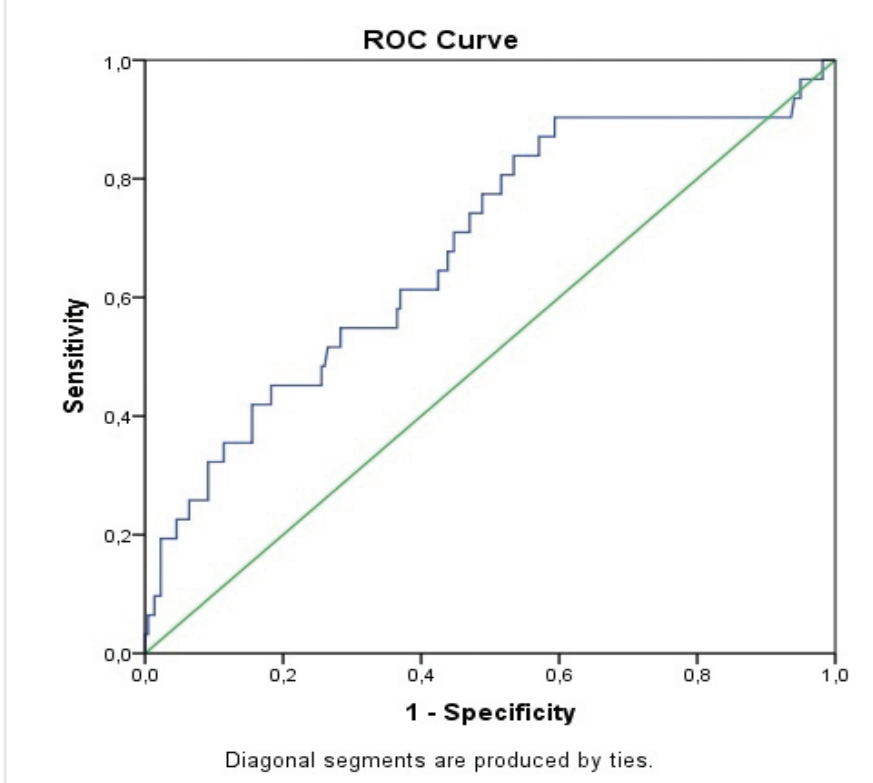

Figure 4. Receiver operating characteristic curve analysis: platelet/ lymphocyte ratio according to in-hospital mortality in patients treated with intravenous thrombolysis

ROC: Receiver operating characteristic

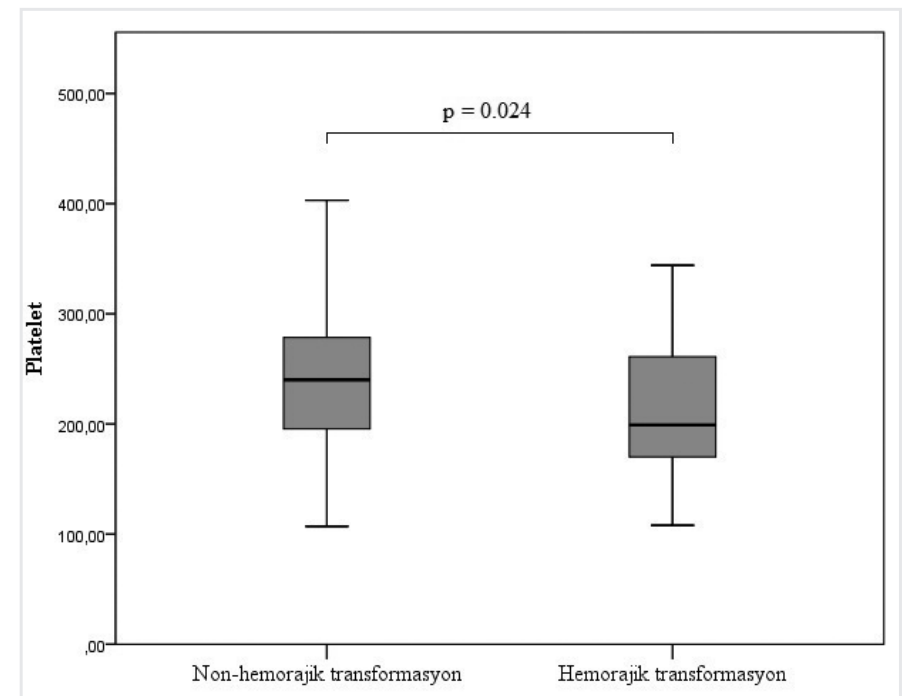

Figure 5. Box plot graph: platelet/lymphocyte ratio according to hemorrhagic transformation in patients treated with intravenous thrombolysis

\section{Discussion}

This is the second study in the literature to evaluate the relationship between mortality, disability, and the PLR in AIS patients treated with IVT (13). In our study, the cut-off point was hospital discharge time. In another study, the 90 day prognosis and mortality were evaluated.

Lymphocyte and platelet levels are important in the pathogenesis and prognosis of ischemic vascular diseases (especially ischemic stroke and myocardial infarction). Increased platelet levels and decreased lymphocyte levels are associated with severe disability and poor

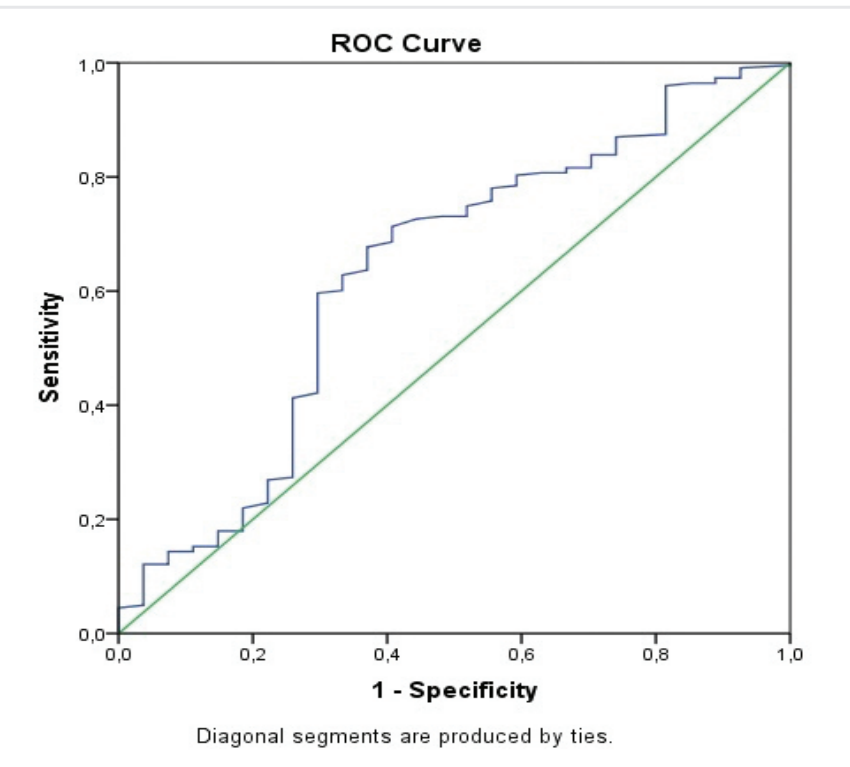

Figure 6. Receiver operating characteristic curve analysis: platelet/ lymphocyte ratio according to hemorrhagic transformation in patients treated with intravenous thrombolysis

ROC: Receiver operating characteristic

prognosis in ischemia (14-17). Overactivation of platelets during ischemic stroke causes thrombosis and vascular occlusion (18). In this process, increased stress activates the hypothalamus-pituitary-adrenal glands. As a result of increased cortisol, the lymphocyte concentration is partially reduced (19). In our study, the lymphocyte level was lower in groups with high initial disability and mortality. This result suggested that the lymphocyte level may be related to prognosis and disability in stroke patients treated with IVT.

The relationship of the PLR with ischemic vascular diseases has been reviewed in the literature. As the PLR increases, the risk of peripheral vascular occlusion increases. In addition, PLR is associated with occurrence of vascular events $(11,20)$. The PLR has been shown to be an independent predictor of cardiovascular disease recurrence and inhospital mortality in patients with acute myocardial infarction $(21,22)$. In stable angina pectoris, the PLR is higher in patients with decreased coronary collateral flow (23). Regarding the ischemic stroke-PLR relationship, an increased PLR is an independent predictor of stroke (24). A higher PLR is associated with increased cerebral ischemia volume and poor recanalization in patients with ischemic stroke treated with endovascular mechanical thrombectomy. In addition, an increased PLR is associated with postoperative stroke risk and depression after carotid endarterectomy $(25,26)$.

In an earlier study, investigating the PLR in AIS patients treated with IVT, blood samples were drawn within the first 24 hours after symptom onset, and patients were evaluated after 3 months. The PLR was higher in patients with unfavorable outcomes. After 3 months, 38 (13.3\%) of these patients died. The PLR was higher in these patients. In conclusion, a high PLR in this study was associated with unfavorable outcomes and death in patients with ischemic stroke treated with IVT (13). Platelet and lymphocyte values can be affected by IVT. Therefore, we obtained blood 
samples before treatment. In our study, a high PLR was associated with increased in-hospital mortality and a high initial disability scale score. There was no relationship between short-term clinical improvement and the PLR. In our study, clinical improvement was evaluated between the pre-discharge and hospitalization period. The relationship with long-term clinical improvement could not be evaluated.

The immune response begins rapidly after ischemic stroke. This is especially associated with disruption of the blood-brain barrier structure. Lymphocytes and platelets are blood cells that actively participate in this process, and they are associated with the severity of stroke (5-7). The lymphocyte value is a predictive marker for microvascular occlusion $(27,28)$. A low platelet level is associated with increased symptomatic intracerebral hemorrhage in patients with ischemic stroke treated with IVT. The risk of hemorrhagic transformation is higher in thrombocytopenic patients. However, no relationship has been detected between poor outcome risk, mortality, and PLR (29). In our study, the lymphocyte value was lower in patients who died. A low lymphocyte level was associated with increased in-hospital mortality. The Iymphocyte cut-off value was calculated as 1.66 with $68.8 \%$ sensitivity and $67.7 \%$ specificity for mortality. A low platelet level was associated with hemorrhagic transformation. The platelet cut-off value was calculated as 211.0 with $67.7 \%$ sensitivity and $63.0 \%$ specificity for hemorrhagic transformation. There was no relationship between the PLR and hemorrhagic transformation.

\section{Study Limitation}

This study had several limitations. First, it was a retrospective study conducted in only one center. Second, the number of patients included in the study was limited. Third, the difference in PLR (before and after treatment) could not be calculated, and its relationship with prognosis could not be determined. Fourth, the relationship of chronic diseases with the PLR and prognosis could not be evaluated.

\section{Conclusion}

In blood tests before IVT treatment in AIS patients, a low lymphocyte level is associated with the initial severity of stroke disability. Also, a low platelet level is associated with hemorrhagic transformation. A higher PLR is associated with high initial disability and in-hospital mortality. The PLR may be an inexpensive, easily accessible, and effective marker for evaluating stroke severity and predicting mortality.

Ethics Committee Approval: The study was approved by University of Health Sciences Turkey, Konya Training and Research Hospital Ethic Committee (approval number: 38-16, date: 08/05/2020).

Informed Consent: Informed consent was obtained from all patients and/or their relatives routinely before IVT.

Peer-review: Externally peer-reviewed.

Authorship Contributions: Surgical and Medical Practices - F.E., A.D.; Concept - F.E., A.D., G.E.; Design - F.E., A.D., G.E.; Data Collection or Processing - F.E., A.D.; Analysis or Interpretation - F.E., G.E.; Literature Search - F.E., G.E.; Writing - F.E., A.D., G.E.
Conflict of Interest: No conflict of interest was declared by the authors.

Financial Disclosure: The authors declared that this study received no financial support.

\section{References}

1. Johnson CO, Nguyen M, Roth GA, Nichols E, Alam T, Abate D, et al. Global, regional, and national burden of stroke, 1990-2016: a systematic analysis for the Global Burden of Disease Study 2016. Lancet Neurol 2019; 18: 439-58.

2. Liu L, Wang D, Wong KS, Wang Y. Stroke and stroke care in China: huge burden, significant workload, and a national priority. Stroke 2011; 42: 3651-4

3. PowersW], Rabinstein AA, Ackerson T, Adeoye OM, Bambakidis NC, Becker K, et al; American Heart Association Stroke Council. 2018 Guidelines for the Early Management of Patients With Acute Ischemic Stroke: A Guideline for Healthcare Professionals From the American Heart Association/American Stroke Association. Stroke 2018; 49: 46-110.

4. Cheripelli BK, Huang X, Maclsaac R, Muir KW. Interaction of Recanalization, Intracerebral Hemorrhage, and Cerebral Edema After Intravenous Thrombolysis. Stroke 2016; 47: 1761-7.

5. Xu XR, Zhang D, Oswald BE, Carrim N, Wang X, Hou Y, et al. Platelets are versatile cells: New discoveries in hemostasis, thrombosis, immune responses, tumor metastasis and beyond. Crit Rev Clin Lab Sci 2016; 53: 409-30.

6. Westrick R, Fredman G; Early Career Committee. Platelets: Context-Dependent Vascular Protectors or Mediators of Disease. Arterioscler Thromb Vasc Biol 2015; 35: e25-9.

7. Perez-de-Puig I, Miró -Mur F, Ferrer-Ferrer M, Gelpi E, Pedragosa J, Justicia C, et al. Neutrophil recruitment to the brain in mouse and human ischemic stroke. Acta Neuropathol 2015; 129: 239-57.

8. Balta S, Ozturk C. The platelet-lymphocyte ratio: A simple, inexpensive and rapid prognostic marker for cardiovascular events. Platelets 2015; 26: 680-1.

9. Sun XP, Li J, Zhu WW, Li DB, Chen H, Li HW, et al. Impact of Platelet-toLymphocyte Ratio on Clinical Outcomes in Patients With ST-Segment Elevation Myocardial Infarction. Angiology 2017; 68: 346-53.

10. Sung PH, Chen KH, Lin HS, Chu CH, Chiang JY, Yip HK. The Correlation between Severity of Neurological Impairment and Left Ventricular Function in Patients after Acute Ischemic Stroke. J Clin Med 2019; 8: 190.

11. Demirdal T, Sen P. The significance of neutrophil-lymphocyte ratio, plateletlymphocyte ratio and lymphocyte-monocyte ratio in predicting peripheral arterial disease, peripheral neuropathy, osteomyelitis and amputation in diabetic foot infection. Diabetes Res Clin Pract 2018; 144: 118-25.

12. Adams HP Jr, Davis PH, Leira EC, Chang KC, Bendixen BH, Clarke WR, et al. Baseline NIH Stroke Scale score strongly predicts outcome after stroke: A report of the Trial of Org 10172 in Acute Stroke Treatment (TOAST). Neurology 1999; 53: 126-31.

13. Xu JH, He XW, Li Q, Liu JR, Zhuang MT, Huang FF, et al. Higher Platelet-toLymphocyte Ratio Is Associated With Worse Outcomes After Intravenous Thrombolysis in Acute Ischaemic Stroke. Front Neurol 2019; 10: 1192

14. Mueller C, Neumann FJ, Hochholzer W, Trenk D, Zeller T, Perruchoud AP, et al The impact of platelet count on mortality in unstable angina/non-ST-segment elevation myocardial infarction. Am Heart J 2006; 151: 1214.e1-7.

15. YangM, Pan Y, Li Z, Yan H, Zhao X, Liu L, et al. Platelet Count Predicts Adverse Clinical Outcomes After Ischemic Stroke or TIA: Subgroup Analysis of CNSR II. Front Neurol 2019; 10: 370

16. Forteza MJ, Trapero I, Hervas A, de Dios E, Ruiz-Sauri A, Minana G, et al. Apoptosis and Mobilization of Lymphocytes to Cardiac Tissue Is Associated with Myocardial Infarction in a Reperfused Porcine Model and Infarct Size in Post-PCI Patients. Oxid Med Cell Longev 2018; 2018: 1975167. 
17. Eren F, Yıldoğan AT, Öngün G, Turan Ișik M, Öztürk Ș. The prognostic value of hematological and biochemical parameters in ischemic stroke patients treated with thrombolytic therapy. Pamukkale Med J 2019; 12: 235-41.

18. Franks ZG, Campbell RA, Weyrich AS, Rondina MT. Platelet-leukocyte interactions link inflammatory and thromboembolic events in ischemic stroke. Ann N Y Acad Sci 2010; 1207: 11-7.

19. Maisel AS, Knowlton KU, Fowler P, Rearden A, Ziegler MG, Motulsky HJ, et al. Adrenergic control of circulating lymphocyte subpopulations. Effects of congestive heart failure, dynamic exercise, and terbutaline treatment. J Clin Invest 1990; 85: 462-7.

20. Gary T, Pichler M, Belaj K, Hafner F, Gerger A, Froehlich H, et al. Plateletto-lymphocyte ratio: a novel marker for critical limb ischemia in peripheral arterial occlusive disease patients. PLoS One 2013; 8: 67688.

21. Ozcan Cetin EHO, Cetin MS, Aras D, Topaloglu S, Temizhan A, Kisacik HL, et al. Platelet to Lymphocyte Ratio as a Prognostic Marker of In-Hospital and Long-Term Major Adverse Cardiovascular Events in ST-Segment Elevation Myocardial Infarction. Angiology 2016; 67: 336-45.

22. Temiz A, Gazi E, Güngör O, Barutçu A, Altun B, Bekler A, et al. Platelet/ lymphocyte ratio and risk of in-hospital mortality in patients with ST-elevated myocardial infarction. Med Sci Monit 2014; 20: 660-5.

23. Açar G, Kalkan ME, Avci A, Alizade E, Tabakci MM, Toprak C, et al. The relation of platelet-lymphocyte ratio and coronary collateral circulation in patients with stable angina pectoris and chronic total occlusion. Clin Appl Thromb Hemost 2015; 21: 462-8.

24. Altintas O, Tasal A, Niftaliyev E, Kucukdagli OT, Asil T. Association of plateletto-lymphocyte ratio with silent brain infarcts in patients with paroxysmal atrial fibrillation. Neurol Res 2016; 38: 753-8.

25. Deșer SB, Yucel SM, Demirag MK, Guclu MM, Kolbakir F, Keceligil HT. The association between platelet/lymphocyte ratio, neutrophil/lymphocyte ratio, and carotid artery stenosis and stroke following carotid endarterectomy. Vascular 2019; 27: 604-11.

26. Huang G, Chen H, Wang Q, Hong X, Hu P, Xiao M, et al. High platelet-tolymphocyte ratio are associated with post-stroke depression. J Affect Disord 2019; 246: 105-11.

27. Urra X, Cervera A, Villamor N, Planas AM, Chamorro A. Harms and benefits of lymphocyte subpopulations in patients with acute stroke. Neuroscience 2009; 158: 1174-83.

28. Bodí V, Sanchis J, Núñez J, Rumiza E, Mainar L, López-Lereu MP, et al. Postreperfusion lymphopenia and microvascular obstruction in ST-segment elevation acute myocardial infarction. Rev Esp Cardiol 2009; 62: 1109-17.

29. Gensicke H, Al Sultan AS, Strbian D, Hametner C, Zinkstok SM, Moulin S, et al. Intravenous thrombolysis and platelet count. Neurology 2018; 90: 690-7. 